\title{
OPTIMALISASI KAPASITAS TRAFIK DENGAN TRANSCEIVER GROUP SYNCHRONIZATION DI PT XL AXIATA TbK PURWOKERTO
}

\author{
Alfin Hikmaturokhman ${ }^{1}$ Anggun Fitrian Isnawati ${ }^{2}$ Febry Setyadillah $^{3}$ \\ Program Studi D-III Teknik Telekomunikasi \\ Akademi Teknik Telkom Sandhy Putra Purwokerto \\ Alfin_h21@yahoo.com ${ }^{1}$, anggun_fitrian@yahoo.com², viebray@yahoo.com ${ }^{3}$
}

\begin{abstract}
ABSTRAK
Perkembangan pengguna telekomunikasi bergerak selular GSM menuntut adanya optimalisasi kapasitas trafik agar mencakup pelanggan semaksimal mungkin. Salah satu cara meningkatkan kapasitas trafik dengan melakukan Transceiver Group Synchronization yaitu penggabungan dua Radio Base Station atau lebih menjadi satu Site. Dengan dilakukan Transceiver Group Synchronization akan meningkatkan kapasitas Traffic Channel (TCH) Availibility, TCH traffic, Stand Alone Dedicated Control Channel (SDCCH), menurunkan TCH Assigment Drop Call dan TCH Congestion Ratio. Dengan ini akan meningkatkan Handover Success Ratio (HOSR) dan menyimpan penggunaan Transceiver Unit (TRU).
\end{abstract}

Kata Kunci: Optimalisasi, Trafik, Transceiver Group Synchronization

\begin{abstract}
Growth of consumer of peripatetic telecommunications of cellular GSM claims the existence of optimal capacities of traffic to be including maximum customer. One of the improving capacities of traffic by Transceiver Group Synchronization that is merger two Radio Bases of Station or more become one Site. Conducted by Transceiver Group Synchronization will improve capacities of Traffic Channel (TCH) Availability, TCH Traffic, Stand Alone Dedicated Control Channel (SDCCH), degrading TCH Assignment Drop Call and of TCH Congestion Ratio. Herewith will improve Handover Success Ratio (HOSR) and of saving usage of Transceiver Unit (TRU).
\end{abstract}

Keywords: Optimalization, Traffic, Transceiver Group Synchronization

\section{Pendahuluan}

\subsection{Latar Belakang}

Saat ini selular telah digunakan oleh jutaan user di seluruh dunia. Pertumbuhan jumlah user naik secara eksponensial setiap tahunnya. Pertumbuhan jumlah user yang besar, menuntut pihak operator harus bisa memenuhi jumlah pelanggan yang semakin lama semakin meningkat pesat.

Dari berbagai teknologi yang berkembang di Indonesia, teknologi Global System for Mobile Communication (GSM) merupakan teknologi operator selular yang perkembangan jumlah pelanggannya sangat cepat dan mempunyai

banyak pelanggan di Indonesia.

Teknologi GSM, membutuhkan perencanaan cell dengan tujuan untuk dapat memenuhi kebutuhan pencakupan cell yang ditunjukan oleh jumlah base station, dimana diusahakan seminimal mungkin dapat memenuhi kebutuhan kapasitas trafik. Dengan tujuan menambah kapasitas trafik tapi tanpa menambahkan cell yang akan menguntungkan dari sisi Radio Frequency (RF) dan pengaturan frekuensinya.

Dengan adanya jumlah pelanggan yang 
meningkat dengan cepat dan jumlah pelanggan selular yang banyak maka operator selular harus meningkatkan kapasitas trafik dengan memanfaatkan teknologi yang sudah ada di operator selular yaitu GSM 900 dan GSM 1800/Digital Cellular System (DCS) 1800. Dengan cara menggabungkan teknologi tersebut untuk meningkatkan kapasitas trafik.

Untuk melakukan penggabungan teknologi GSM 900 dan DCS 1800 diperlukan penggabungan 2 transceiver group dalam 1 cell dengan beda Channel Group (CHGR), menjadikan koneksi antara Base Transceiver Station (BTS) pada Multiband yang satu jadi master dan yang lain menjadi slave. Slave akan dikontrol oleh Master. Koneksi antara Distribution Switch Unit (DXU) GSM 900 dan DXU GSM 1800 dengan menggunakan sebuah kabel yang disebut dengan kabel External Synchronization Bus (ESB). Oleh karena itu dalam pembahasan penelitian ini, penulis ingin melakukan "Optimalisasi Kapasitas Trafik dengan Transceiver Group Synchronization di PT XL AXIATA, Tbk Purwokerto" sebagai bentuk penelitian terhadap cara meningkatkan kapasitas trafik tanpa menambahkan cell dengan berbagi jumlah kanal pada 2 BTS atau lebih.

\subsection{Perumusan Masalah}

Berdasarkan uraian di atas terdapat permasalahan yang perlu dikaji lebih lanjut, yaitu:

1. Bagaimana meminimalkan loss Resource dan meningkatkan kapasitas trafik menggunakan traffic gain dengan satu Broadcast Control Channel (BCCH) di Overlay 1 dan Overlay 2?

2. Bagaimana menemukan solusi untuk BTS end site high traffic?

\subsection{Maksud Penulisan}

Adapun maksud pembuatan Tugas

Akhir ini adalah:

1. Melakukan upaya optimalisasi kapasitas trafik dengan Transceiver Group Synchronization.

2. Melakukan upaya optimalisasi untuk meningkatkan kapasitas trafik tanpa menambahkan cell.

\subsection{Batasan Masalah}

Pembahasan dalam Tugas Akhir ini akan dibatasi pada beberapa masalah sebagai berikut :

1. Tidak membahas optimalisasi yang dilakukan secara software.

2. Hanya membahas Distribution switch Unit (DXU), tidak untuk perangkat-perangkat jaringan GSM maupun DCS yang lain.

3. Tidak melihat kenaikan drop call akibat kekuatan sinyal dengan posisi antena BTS OL1 dan OL2 yang tidak sejajar.

4. Tidak membahas jenis ESB cable yang digunakan.

5. Tidak membahas software Operation and Maintenance (OMT) versi 37 yang digunakan. 
6. Adapun parameter-parameter yang dianalisa pada jaringan GSM 900 dan DCS 1800 di PT XL AXIATA, Tbk Purwokerto antara lain Traffic Channel (TCH) Availability, TCH Congestion Ratio, TCH Traffic, Stand Alone Dedicated Control Channel (SDCCH) Traffic, dan TCH Drop Call Assignment.

7. Tidak membahas jenis-jenis antena yang digunakan.

8. Data yang dianalisa hanya untuk suara (voice).

\section{Analisis Data dan Pembahasan}

\subsection{Pendahuluan}

Sebagai salah satu operator terbesar jaringan GSM di Indonesia, PT XL AXIATA, Tbk akan terus memberikan layanan yang terbaik dan mencakup seluruh pelanggannya. Salah satunya dengan meningkatkan kapasitas trafik jaringan PT XL AXIATA, Tbk dengan menggabungkan band GSM 900 dengan GSM 1800 / DCS 1800 ataupun GSM 900. Salah satu Regional yang dinilai memiliki jumlah pelanggan yang banyak dan terus meningkat adalah Regional Jateng dan DI Yogyakarta. Oleh karena itu dilakukan peningkatan kapasitas trafik dengan Transceiver Group Synchronization. Parameter-parameter yang dianalisis adalah sebagai berikut :

\section{TCH Availability}

2. TCH Congestion Ratio

\section{TCH Traffic}

4. SDCCH Traffic

5. TCH Drop Assignment Ratio
Parameter-parameter tersebut diambil dari 5 site pada Regional Jateng dan DI Yogyakarta dengan pengambilan data di XL AXIATA, Tbk area Purwokerto.

Pengambilan data dilakukan dengan menggunakan sofware QAReport Web Version PT XL AXIATA, Tbk Purwokerto kemudian hasil pengambilan dari software tersebut menghasilkan Statistics and Traffic Measurement System (STS).

Berikut daftar dan nama cell-cell yang site Regional Jateng dan DI Yogyakarta yang datanya diambil untuk analisis data sebelum dan sesudah dilakukan TG Synchronization pada bulan April 2010, Mei 2010, dan Juni 2010 berikut ini:

1. Daftar dan nama site-site $\mathrm{PT} \mathrm{XL}$ AXIATA, Tbk Regional Jateng dan DI Yogyakarta pada bulan April 2010.

Tabel 1 Daftar dan nama site-site PT XL AXIATA, Tbk Regional Jateng dan DI Yogyakarta pada bulan April 2010.

\begin{tabular}{|c|c|l|}
\hline No. & Cell Id & \multicolumn{1}{c|}{ Nama Site } \\
\hline 1. & 49017 & Karang Kebumen \\
\hline 2. & 49018 & Karang Kebumen \\
\hline 3. & 49019 & Karang Kebumen \\
\hline
\end{tabular}

2. Daftar dan nama site-site PT XL AXIATA, Tbk Regional Jateng dan DI Yogyakarta pada bulan Mei 2010.

Tabel 2 Daftar dan nama site-site PT XL AXIATA, Tbk Regional Jateng dan DI Yogyakarta pada bulan Mei 2010.

\begin{tabular}{|c|c|l|}
\hline No. & Cell Id & \multicolumn{1}{|c|}{ Nama Site } \\
\hline 1. & 24701 & Nglipar \\
\hline 2. & 24702 & Nglipar \\
\hline 3. & 24703 & Nglipar \\
\hline
\end{tabular}


3. Daftar dan nama site-site PT XL AXIATA, Tbk Regional Jateng dan DI Yogyakarta pada bulan Juni 2010.

Tabel 3 Daftar dan nama site-site PT XL AXIATA, Tbk Regional Jateng dan DI Yogyakarta pada bulan Mei 2010.

\begin{tabular}{|c|c|l|}
\hline No. & Cell Id & \multicolumn{1}{|c|}{ Nama Site } \\
\hline 1. & 49017 & Karang Kebumen \\
\hline 2. & 49018 & Karang Kebumen \\
\hline 3. & 49019 & Karang Kebumen \\
\hline 4. & 23431 & Cilongok \\
\hline 5. & 23432 & Cilongok \\
\hline 6. & 23433 & Cilongok \\
\hline 7. & 38604 & Bantarsari \\
\hline 8. & 38605 & Bantarsari \\
\hline 9. & 38606 & Bantarsari \\
\hline 10. & 24687 & Marungan \\
\hline 11. & 24688 & Marungan \\
\hline 12. & 24689 & Marungan \\
\hline
\end{tabular}

Berikut daftar dan nama cell-cell yang site Regional Jateng dan DI Yogyakarta yang datanya diambil untuk pengaruh TG Synchronization pada jumlah Transceiver Unit, pada bulan Maret 2010 sesuai tabel 4 berikut ini:

Tabel 4 Daftar dan nama site-site PT XL AXIATA, Tbk Regional Jateng dan DI Yogyakarta pada bulan Maret 2010.

\begin{tabular}{|c|l|l|}
\hline No. & \multicolumn{1}{|c|}{ Cell Id } & \multicolumn{1}{|c|}{ Nama Site } \\
\hline 1. & 58007 & Gandramangu2 \\
\hline 2. & 58008 & Gandramangu2 \\
\hline 3. & 58009 & Gandramangu2 \\
\hline 4. & 55177 & Bojongsari2 \\
\hline 5. & 55178 & Bojongsari2 \\
\hline 6. & 55179 & Bojongsari2 \\
\hline 7. & 29807 & Temanggung2 \\
\hline 8. & 29808 & Temanggung2 \\
\hline 9. & 29809 & Temanggung2 \\
\hline 10. & 30331 & Wonosobo2 \\
\hline 11. & 30332 & Wonosobo2 \\
\hline 12. & 30333 & Wonosobo2 \\
\hline
\end{tabular}

2.2Standarisasi dari PT XL AXIATA, Tbk

Tabel 5 Standarisasi dari PT XL AXIATA, Tbk

\begin{tabular}{|c|c|c|c|c|c|}
\hline \multirow{2}{*}{$\begin{array}{l}\mathrm{N} \\
\mathrm{o}\end{array}$} & \multirow{2}{*}{$\begin{array}{l}\text { Paramet } \\
\text { er GSM }\end{array}$} & \multicolumn{3}{|c|}{$\begin{array}{c}\text { Perfomansi Standar } \\
(\%)\end{array}$} & \multirow{2}{*}{$\begin{array}{c}\text { Performa } \\
\text { nsi XL } \\
(\%)\end{array}$} \\
\hline & & $\begin{array}{c}\text { Bai } \\
k\end{array}$ & $\begin{array}{c}\text { Norm } \\
\text { al }\end{array}$ & $\begin{array}{c}\text { Kura } \\
\text { ng }\end{array}$ & \\
\hline 1. & $\begin{array}{l}\text { TCH } \\
\text { Congesti } \\
\text { on Rate }\end{array}$ & $\begin{array}{c}<1, \\
0\end{array}$ & $\begin{array}{l}1,0- \\
2,0\end{array}$ & $>2,0$ & $1,1^{*}$ \\
\hline 2. & $\begin{array}{l}\text { Drop } \\
\text { Call } \\
\text { Rate }\end{array}$ & $\begin{array}{c}<1, \\
0\end{array}$ & $\begin{array}{l}1,0- \\
2,0\end{array}$ & $>2,0$ & $1,2 *$ \\
\hline
\end{tabular}

Keterangan : * = Baik

Tabel 6 Standarisasi Utilisasi $\mathrm{TCH}$ dari PT XL AXIATA, Tbk

\begin{tabular}{|l|l|c|}
\hline No. & $\begin{array}{c}\text { Parameter } \\
\text { GSM }\end{array}$ & $\begin{array}{c}\text { Performansi Standar } \\
(\%) \\
\text { Kanal Logik } \\
\text { TCH }\end{array}$ \\
\hline 1. & Utilisasi & 80 \\
\hline
\end{tabular}

\subsection{Analisis Data}

\section{Parameter-parameter yang digunakan}

Dalam melakukan analisis data yang diolah sebagaimana dapat dilihat pada lampiran I, lampiran II, lampiran III sampai dengan lampiran XVI. Data pada lampiran tersebut sebenarnya merupakan hasil pengolahan data dari mentah yang diperoleh dari STS.

Data tersebut diolah berdasarkan parameter-parameter sebagai berikut:

\section{a. TCH Availability}

Parameter TCH Availability merupakan suatu parameter yang menunjukan nilai dari kapasitas $\mathrm{TCH}$ yang tersedia.

\section{b. TCH Congestion Ratio}

Parameter TCH Congestion Ratio merupakan prosentase kegagalan panggilan karena tidak mendapatkan kanal TCH. 
c. TCH traffic

Parameter TCH traffic merupakan suatu parameter yang menunjukkan tingkat $\mathrm{TCH}$ yang digunakan oleh pelanggan.

\section{d. SDCCH traffic}

Parameter SDCCH traffic merupakan suatu parameter yang menunjukkan tingkat traffic SDCCH yang digunakan oleh pelanggan.

\section{e. TCH Drop Assignment ratio}

Parameter Drop Assignment Ratio adalah suatu parameter yang menunjukkan tingkat kegagalan user dalam melakukan panggilan setelah berhasil dilakukan namun berakhir tanpa pemutusan panggilan secara normal.

\section{Analisis Data}

\section{a. $\mathrm{TCH}$ Availability}

Sesuai pada gambar 1, gambar 2, dan gambar $3 \mathrm{TCH}$ Availability meningkat pada tanggal 17 Mei 2010 yang awalnya pada tanggal 1 Mei sampai 16 Mei 2010 kapasitas TCH Availability sebesar 28 time slot meningkat menjadi 58 time slot sesudah dilakukan TG Sychronization pada Site tersebut. Itu terjadi karena adanya penggabungan kedua time slot RBS yaitu 28 time slot yang dimiliki oleh master RBS ditambahkan dengan 28 time slot milik slave RBS tersebut dan ditambahkan 2 time slot yang awalnya digunakan untuk signaling sehingga menjadi 58 time slot. Hal tersebut dikarenakan dengan penggabungan kedua RBS akan memerlukan satu $\mathrm{BCCH}$ saja yaitu hanya pada Master RBS saja. Peningkatan pada tanggal 17 Mei 2010 baru mencapai 40, hal ini dikarenakan masih dalam proses TG Synchronization, diperlukan 1x24 jam untuk proses maksimal pengoptimalan jumlah trafik sesudah dilakukan TG synchronization. Untuk tanggal 28-29 Mei 2010 tidak dapat dilakukan pengambilan data karena sedang perbaikan server jaringan.

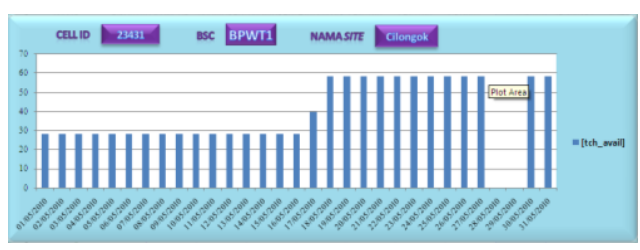

Gambar 1 TCH Availability pada Site Cilongok Cell ID 23431 bulan Mei 2010



Gambar 2 TCH Availability pada Site Cilongok Cell ID 23432 bulan Mei 2010

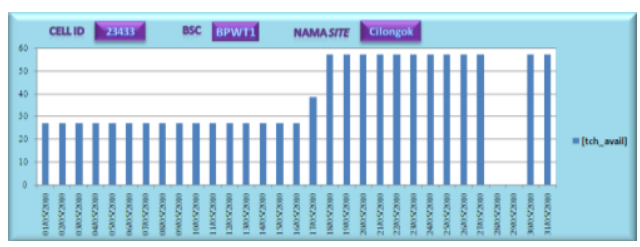

Gambar 3 TCH Availability pada Site

Cilongok Cell ID 23433 Bulan Mei 2010

Dengan melakukan TG Synchronization terjadi peningkatan kapasitas trafik sesuai pada gambar 3.1, gambar 3.2, dan gambar 3.3 yang datanya diambil dari lampiran I, lampiran II, dan lampiran III. Dengan itu bahwa yang seharusnya 2 RBS digabungkan jumlah Time Slotnya 56, dengan setiap RBS mempunyai 28 time slot. Tetapi dengan melakukan TG Synchronization tersebut terjadi peningkatan 58 time slot itu dikarenakan peningkatan kapasitas trafik 
menggunakan traffic gain. Yang awalnya setiap RBS mempunyai satu BCCH, jadi 2 RBS mempunyai 2 BCCH. Dengan melakukan TG Synchronization hanya Master RBS saja yang memerlukan BCCH karena Master RBS mengontrol Slave RBS.

Dengan melakukan TG Synchronication merupakan salah satu solusi untuk BTS end site high traffic, dapat menambahkan kapasitas trafik tanpa penambahan cell/BTS. Dapat dilihat pada peningkatan $\mathrm{TCH}$ availabilitynya yang meningkat menjadi 2 kali lipat dari awalnya yaitu 28 time slot menjadi 58 time slot. Dengan itu penambahan kapasitas trafik bisa dilakukan tanpa penambahan cell/BTS.

\section{b. TCH Congestion Ratio}

Alasan utama melakukan TG synchronization karena tingginya nilai porsentase kegagalan panggilan karena tidak mendapatkan kanal TCH. Berdasarkan data lampiran I, lampiran II dan lampiran III maka dapat diambil nilai rata-rata $\mathrm{TCH}$ congestion ratio sebelum dan sesudah dilakukan TG Synchronization pada site Cilongok seperti pada tabel 7 berikut ini.

Tabel 7 Nilai rata-rata TCH Congetion Ratio pada site Cilongok pada bulan Mei 2010.

\begin{tabular}{|c|c|c|c|c|}
\hline \multirow[b]{2}{*}{$\begin{array}{l}\text { Cell } \\
I D\end{array}$} & \multicolumn{2}{|c|}{$\begin{array}{c}\text { TCH Congestion } \\
\text { Ratio }\end{array}$} & \multirow[b]{2}{*}{$\begin{array}{c}\text { Standa } \\
\text { r XL } \\
\text { Axiata }\end{array}$} & \multirow[b]{2}{*}{ Ket } \\
\hline & $\begin{array}{l}\text { Sebelum } \\
\text { TG } \\
\text { Synchron } \\
\text { ization }\end{array}$ & $\begin{array}{c}\text { Sesudah } \\
\text { TG } \\
\text { Synchron } \\
\text { ization }\end{array}$ & & \\
\hline 23431 & $2,20 \%$ & $0,58 \%$ & $1,1 \%$ & Baik \\
\hline 23432 & $2,46 \%$ & $0,56 \%$ & $1,1 \%$ & Baik \\
\hline 23433 & $50,71 \%$ & $1,71 \%$ & $1,1 \%$ & Baik \\
\hline
\end{tabular}

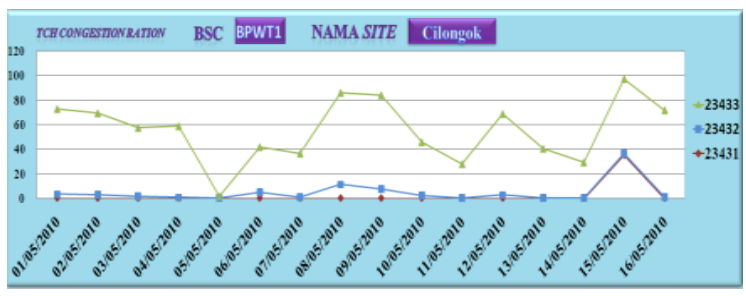

Gambar 4 TCH congestion ratio pada Site Cilongok Cell ID 23431, 23432, dan 23433 pada tanggal 1 Mei sampai 16 Mei 2010.

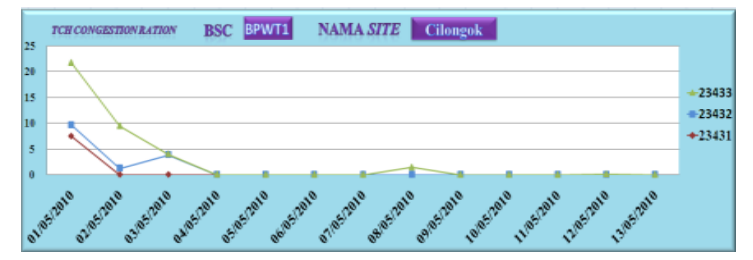

Gambar 5 TCH congestion ratio pada Site Cilongok Cell ID 23431, 23432, dan 23433 pada tanggal 17 Mei sampai 31 Mei 2010.

Sesuai pada tabel 7 dan gambar 4 yang datanya diambil dari lampiran I, lampiran II, dan lampiran III maka dilakukan TG Synchronization. Itu dikarenakan oleh tingginya nilai rata-rata $\mathrm{TCH}$ Congestion Ratio pada site Cilongok dari tanggal 1 Mei sampai 16 Mei 2010 yaitu 2,20\% untuk cell ID 23431, 2,46\% untuk cell ID 23432 dan 50,71\% untuk cell ID 23433. Nilai-nilai tersebut melebihi nilai standar yang ditetapkan oleh PT XL AXIATA, Tbk sesuai pada tabel 5 .

Dari tabel 7, gambar 4 dan gambar 5 yang datanya dari lampiran I dapat diambil nilai rata-rata dari TCH Congestion Ratio cell ID 23431 sebelum dilakukan TG Synchronization dan sesudah dilakukan TG Synchronization. Nilai rata-rata $\mathrm{TCH}$ Congestion Ratio-nya sebelum dilakukan TG Synchronization adalah $2,20 \%$ dan sesudah dilakukan TG Synchronization nilai rata-rata TCH Congestion Ratio-nya menurun menjadi $0,58 \%$. Terlihat 
seperti pada grafik gambar 5 pada cell ID 23431 bahwa terjadi penurunan nilai TCH congestion ratio dibawah standar dari PT XL AXIATA, Tbk yang sesuai pada tabel 5 berarti terjadi penurunan kegagalan panggilan karena tidak mendapatkan kanal TCH.

Dari tabel 7, gambar 4 dan gambar 5 yang datanya dari lampiran II dapat diambil nilai rata-rata dari $\mathrm{TCH}$ Congestion Ratio cell ID 23432 sebelum dan sesudah dilakukan TG Synchronization. Nilai rata-rata TCH Congestion Ratio-nya sebelum dilakukan TG Synchronization adalah $2,46 \%$ dan sesudah dilakukan TG Synchronization nilai rata-rata TCH Congestion Ratio-nya menurun menjadi $0,56 \%$. Terlihat seperti pada grafik gambar 5 pada cell ID 23432 bahwa terjadi penurunan nilai TCH congestion ratio dibawah standar dari PT XL AXIATA, Tbk yang sesuai pada tabel 5 berarti terjadi penurunan kegagalan panggilan karena tidak mendapatkan kanal TCH.

Dari tabel 7, gambar 4 dan gambar 5 yang datanya dari lampiran III dapat diambil nilai rata-rata dari TCH Congestion Ratio cell ID 23433 sebelum dan sesudah dilakukan TG Synchronization. Pada sebelum dilakukan TG Synchronization nilai rata-rata $\mathrm{TCH}$ Congestion Ratio-nya adalah 50,71\% dan setelah dilakukan TG Synchronization nilai rata-rata $\mathrm{TCH}$ Congestion Ratio-nya menurun menjadi 1,71\%. Walaupun pada cell ID $23433 \mathrm{TCH}$ congestion ratio tidak sesuai dengan standar PT XL AXIATA, Tbk yaitu tabel 5. Tetap dianggap terjadi penurunan kegagalan panggilan karena tidak mendapatkan kanal $\mathrm{TCH}$, dilihat dari perhari/pertanggalnya sesuai pada grafik gambar 5 cell ID 23433 yang datanya diambil dari lampiran III.

Dengan melakukan TG Synchronization dapat meminimalkan loss resource (tidak mendapatkan kanal TCH waktu melakukan panggilan) ditunjukan dengan terjadinya penurunan TCH Congestion Ratio dibawah standar TCH Congestion Ratio pada PT XL AXIATA, Tbk sesuai tabel 5. Dan hasil tersebut bisa dilihat pada tabel 7 yang datanya diambil dari lampiran I, Lampiran II, dan Lampiran III.

c. TCH traffic

Terjadi peningkatan kapasitas trafik pada TCH traffic sesudah TG Synchronization. Sebelum pelaksanaan TG Synchronization nilai rata-rata dari $\mathrm{TCH}$ traffic-nya misalnya 18 Erlang setelah melakukan TG Synchronization sehingga nilai dari TCH traffic-nya akan meningkat menjadi 36 Erlang. Itu dikarenakan penggabungan kedua $\mathrm{TCH}$ traffic yang dimiliki master RBS dan slave RBS menjadi satu. Tetapi pada kasus site Cilongok setelah dilakukan TG Synchronization nilai rata-rata $\mathrm{TCH}$ Traffic terjadi penurunan sesuai pada tabel 8 , itu dikarenakan jumlah pelanggan yang menggunakan panggilan telepon lebih sedikit pada saat setelah dilakukan TG Synchronization dan lebih banyak pelanggan yang menggunakan layanan pesan daripada voice. Disebabkan karena maraknya promo pesan dari PT XL AXIATA, Tbk. 
Tabel 8 Nilai rata-rata TCH traffic pada site Cilongok pada bulan Mei 2010.

\begin{tabular}{|c|c|c|}
\hline \multirow{2}{*}{$\begin{array}{c}\text { Cell } \\
\text { ID }\end{array}$} & \multicolumn{2}{|c|}{ TCH Traffic } \\
\cline { 2 - 3 } & $\begin{array}{c}\text { Sebelum TG } \\
\text { Synchronization }\end{array}$ & $\begin{array}{c}\text { Sesudah TG } \\
\text { Synchronization }\end{array}$ \\
\hline 23431 & 15,59 Erlang & 10,96 Erlang \\
\hline 23432 & 23,30 Erlang & 20,21 Erlang \\
\hline 23433 & 30,16 Erlang & 25,15 Erlang \\
\hline
\end{tabular}

\section{d. SDCCH Traffic}

Terjadi peningkatan kapasitas trafik pada SDCCH traffic sesudah TG Synchronization. Dapat dilihat dari tabel 9, sebelum dilakukan TG Synchronization nilai rata-rata dari SDCCH traffic site Cilongok pada cell ID 23431 adalah 4,18 Erlang dan setelah melakukan TG Synchronization maka nilai ratarata dari SDCCH traffic-nya meningkat menjadi 4,96 Erlang. Itu dikarenakan penggabungan kedua SDCCH traffic yang dimiliki master RBS dan slave RBS menjadi satu.

Dapat dilihat pada tabel 9 pada cell ID 23432 yang datanya diambil pada lampiran II sebelum dilakukan TG Synchronization nilai rata-rata SDCCH traffic-nya adalah 4,46 Erlang dan setelah dilakukan TG Synchronization menjadi 4,66 Erlang. Itu dikarenakan penggabungan kedua SDCCH traffic yang dimiliki master RBS dan slave RBS menjadi satu.

Dapat dilihat pada tabel 9 pada cell ID 23433 yang datanya diambil pada lampiran III sebelum dilakukan TG Synchronization nilai rata-rata SDCCH traffic-nya adalah 8,89 Erlang dan setelah dilakukan TG Synchronization menjadi 9,10 Erlang. Itu dikarenakan penggabungan kedua SDCCH traffic yang dimiliki master RBS dan slave RBS menjadi satu.

Tabel 9 Nilai rata-rata SDCCH traffic pada site Cilongok pada bulan Mei 2010.

\begin{tabular}{|c|c|c|}
\hline \multirow{2}{*}{$\begin{array}{c}\text { Cell } \\
\text { ID }\end{array}$} & \multicolumn{2}{|c|}{ SDCCH Traffic } \\
\cline { 2 - 3 } & $\begin{array}{c}\text { Sebelum TG } \\
\text { Synchronization }\end{array}$ & $\begin{array}{c}\text { Sesudah TG } \\
\text { Synchronization }\end{array}$ \\
\hline 23431 & 4,18 Erlang & 4,96 Erlang \\
\hline 23432 & 4,46 Erlang & 4,66 Erlang \\
\hline 23433 & 8,89 Erlang & 9,10 Erlang \\
\hline
\end{tabular}

e. TCH Drop Assignment Ratio

Dengan dilakukannya TG Synchronization maka akan berpengaruh pada parameter $\mathrm{TCH}$ Drop Assignment Ratio. Sebelum dilakukan TG Synchronization nilai rata-rata dari TCH Drop Assignment Ratio melebihi dari standar $\mathrm{TCH}$ Drop Assignment Ratio yang ditetapkan oleh PT XL AXIATA, Tbk yaitu sesuai pada tabel 5. Setelah pelaksanaan TG Synchronization maka nilai dari TCH Drop Assignment Ratio-nya akan terjadi penurunan dan penurunan drop call tersebut meningkatkan Handover Success Rate (HOSR). HOSR adalah nilai porsentase suksesnya melakukan perpindahan daerah pelayanan karena terjadi mobilitas pelanggan atau melewati cakupan dari BTS yang awalnya melayani MS tersebut. Karena kegagalan handover salah satu yang mengakibatkan drop call. Peningkatan HOSR tersebut dikarenakan yang awalnya sebelum dilakukan TG Synchronization, proses handover terjadi pada kedua Cell RBS GSM 900 dan Cell RBS GSM 900/1800. Tetapi setelah dilakukan TG Synchronization maka proses handover hanya 
terjadi pada RBS yang menjadi Master. Karena Master RBS mengontrol kinerja dari Slave RBS.

Tabel 10 Nilai rata-rata TCH Drop Assignment Ratio pada site Cilongok pada bulan Mei 2010.

\begin{tabular}{|c|c|c|c|c|}
\hline \multirow[b]{2}{*}{$\begin{array}{l}\text { Cell } \\
I D\end{array}$} & \multicolumn{2}{|c|}{$\begin{array}{c}\text { TCH Drop } \\
\text { Assignment Ratio }\end{array}$} & \multirow[b]{2}{*}{$\begin{array}{c}\text { Standa } \\
\text { r XL } \\
\text { Axiata }\end{array}$} & \multirow[b]{2}{*}{ Ket } \\
\hline & $\begin{array}{c}\text { Sebelu } \\
\text { m TG } \\
\text { Synchr } \\
\text { onizati } \\
\text { on }\end{array}$ & $\begin{array}{c}\text { Sesudah } \\
\text { TG } \\
\text { Synchro } \\
\text { nization }\end{array}$ & & \\
\hline 23431 & $3,98 \%$ & $3,96 \%$ & $1,2 \%$ & $\begin{array}{c}\text { Kurang } \\
\text { Baik }\end{array}$ \\
\hline 23432 & $1,37 \%$ & $2,13 \%$ & $1,2 \%$ & $\begin{array}{c}\text { Kurang } \\
\text { Baik }\end{array}$ \\
\hline 23433 & $1,71 \%$ & $2,62 \%$ & $1,2 \%$ & $\begin{array}{c}\text { Kurang } \\
\text { Baik }\end{array}$ \\
\hline
\end{tabular}

Pada tabel 10 pada cell ID 23431 yang datanya diambil dari lampiran I terjadi penurunan TCH Drop Assignment Ratio sesudah dilakukan TG Synchronization. Dengan nilai rata-rata sebelum melakukan TG Synchronization yaitu pada tanggal 1 Mei sampai 16 Mei 2010 adalah sebesar 3,98\%, kemudian sesudah melakukan TG Synchronization menurun menjadi 3,96 \%. Walaupun nilainya masih diatas TCH Drop Assignment Ratio yang dijadikan standar PT XL AXIATA, Tbk tetapi tetap menurunkan terjadinya drop call yang dapat meningkatkan handover success rate (HOSR). Itu terjadi dikarenakan handover hanya terjadi pada Master RBS dan tidak terjadi pada Slave RBS.

Pada tabel 10 pada cell ID 23432 yang datanya diambil dari lampiran II terjadi peningkatan sesudah dilakukan TG Synchronization. Yang awalnya nilai rata-rata terjadinya drop call sebelum dilakukan TG Synchronization sebesar $1,37 \%$, kemudian sesudah dilakukan TG Synchronization terjadi peningkatan drop call 2,13 \%. Terjadi peningkatan drop call, itu dikarenakan pengaturan tilting antena dan sector antena pada Slave RBS tidak sama dengan Master RBS.

Pada tabel 10 pada cell ID 23433 yang datanya diambil dari lampiran III terjadi peningkatan sesudah dilakukan TG Synchronization. Yang awalnya nilai rata-rata terjadinya drop call sebelum dilakukan TG Synchronization sebesar 1,71\%, kemudian sesudah dilakukan TG Synchronization terjadi peningkatan drop call 2,62 \%. Terjadi peningkatan drop call, itu dikarenakan pengaturan tilting antena dan sector antena pada Slave RBS tidak sama dengan Master RBS.

\section{Pengaruh Tilting dan Sector Antena}

Tilting antena atau yang biasa disebut dengan kemiringan antena dan Sectorisasi antena sangat mempengaruhi TG Synchronization karena arah antena dan kemiringan antena kedua RBS yang di TG Synchronization harus searah, apabila Slave RBS arah antenanya tidak sesuai dengan Master RBS maka akan terjadi MS mendapat sinyal tapi tidak dapat melakukan panggilan dan terjadinya drop call. Sebab Master RBS mengontrol kinerja Slave RBS.

\subsection{Pengaruh TG Synchronization pada jumlah Tranceiver Unit}


Setelah dilakukan TG Synchronization, kita dapat melakukan penyimpanan beberapa TRX/TRU untuk mengoptimalkan penggunaan TRX tersebut.

Tabel 11 Pengaruh TG Synhronization pada jumlah Transceiver Unit site Gandrumangu pada kanal TCH

\begin{tabular}{|c|c|c|c|c|c|c|c|c|c|c|c|}
\hline \multirow[b]{2}{*}{$\begin{array}{l}\mathbf{N} \\
\mathbf{0}\end{array}$} & \multirow[b]{2}{*}{$\begin{array}{l}\text { Cell } \\
\text { ID }\end{array}$} & \multirow{2}{*}{$\begin{array}{l}\text { Pea } \\
\mathbf{k} \\
\text { traf } \\
\text { fic }\end{array}$} & \multicolumn{4}{|c|}{ Present } & \multicolumn{4}{|c|}{ Proposal } & \multirow{2}{*}{\begin{tabular}{|l}
$S$ \\
$a$ \\
$v$ \\
$e$ \\
$\mathbf{T}$ \\
$\mathbf{R}$ \\
$\mathbf{X}$
\end{tabular}} \\
\hline & & & $\begin{array}{l}\mathrm{T} \\
\mathrm{R} \\
\mathrm{X}\end{array}$ & $\begin{array}{l}T \\
S\end{array}$ & E & $\mathrm{U}$ & $\begin{array}{l}\mathrm{T} \\
\mathrm{R} \\
\mathrm{X}\end{array}$ & $\begin{array}{l}\mathrm{T} \\
\mathrm{S}\end{array} \mid$ & $\mathrm{E}$ & $\mathrm{U}$ & \\
\hline 1 & $\begin{array}{l}580 \\
07\end{array}$ & $\begin{array}{l}60, \\
43\end{array}$ & 8 & $\begin{array}{l}5 \\
8\end{array}$ & $\begin{array}{l}4 \\
7\end{array}$ & $\begin{array}{l}12 \\
6, \\
42\end{array}$ & 8 & $\begin{array}{l}5 \\
9\end{array}$ & $\begin{array}{l}4 \\
8 \\
7 \\
7\end{array}$ & $\begin{array}{l}12 \\
4, \\
08\end{array}$ & 0 \\
\hline 2 & $\begin{array}{l}580 \\
08\end{array}$ & $\begin{array}{l}17, \\
87\end{array}$ & 8 & $\begin{array}{l}5 \\
9\end{array}$ & $\begin{array}{l}4 \\
8\end{array}$ & $\begin{array}{l}36 \\
6 \\
9\end{array}$ & 5 & $\begin{array}{l}3 \\
8\end{array}$ & $\begin{array}{l}2 \\
9 \\
2 \\
2\end{array}$ & $\begin{array}{l}61 \\
, 2 \\
0\end{array}$ & 3 \\
\hline 3 & $\begin{array}{l}580 \\
09\end{array}$ & $\begin{array}{l}37, \\
88\end{array}$ & 8 & $\begin{array}{l}5 \\
8\end{array}$ & $\begin{array}{l}4 \\
7\end{array}$ & $\begin{array}{l}79 \\
2 \\
4\end{array}$ & 7 & $\begin{array}{l}5 \\
0\end{array}$ & $\begin{array}{l}4 \\
0 \\
3\end{array}$ & $\begin{array}{c}93 \\
99 \\
9\end{array}$ & 1 \\
\hline
\end{tabular}

Pada tabel 11, pada cell ID 58007 dengan peak traffic-nya selama bulan maret 2010 sebesar 60,43 Erlang dengan jumlah TRX 8, TS 58, kapasitas TCH traffic 47,8 Erlang diperoleh nilai utilisasi $126,42 \%$. Nilai utilisasi didapat dari nilai peak traffic dibagi dengan Erlang. Berarti dengan itu pada cell ID 58007 nilai utilisasi-nya melebih dari standar PT XL AXIATA, Tbk Purwokerto yang sesuai dengan tabel 6. Jadi tidak bisa dilakukan penyimpanan TRX dikarenakan kalau diadakan penyimpanan maka nilai utilisasi tersebut akan meningkat. Dan itu akan mengakibatkan semakin tinggi pelanggan yang tidak tercakup oleh sektor tersebut.
Lihat pada tabel 11, pada cell ID 58008 dengan peak traffic-nya selama bulan maret 2010 sebesar 17,87 Erlang dengan jumlah TRX 8, TS 59, kapasitas TCH traffic 48,7 Erlang diperoleh nilai utilisasi sebesar 36,69\%. Nilai utilisasi didapat dari nilai peak traffic dibagi dengan Erlang. Berarti dengan itu pada cell ID 58008 nilai utilisasi-nya kurang dari standar PT XL AXIATA, Tbk Purwokerto yang sesuai dengan tabel 6. maka diperlukan peningkatan nilai utilisasi agar penggunaan TRX tidak berlebihan atau penggunaan TRX maksimal. Dengan itu disimpan 3 TRX untuk meningkatkan nilai utilisasi-nya sehingga mencapai 61,20\%, untuk kasus ini nilai utilisasi belum melebihi dari standarisasi PT XL AXIATA, Tbk Purwokerto itu dikarenakan pada area yang dicakup oleh sektor tersebut daerah perumahan atau padat. Dilakukan dibawah standar dikarenakan untuk menjaga kenaikan pelanggan yang meningkat mendadak.

Lihat pada tabel 11, pada cell ID 58009 dengan peak traffic-nya selama bulan maret 2010 sebesar 37,88 Erlang dengan jumlah TRX 8, TS 58, kapasitas TCH traffic 47,8 Erlang diperoleh nilai utilisasi 79,24\%. Nilai utilisasi didapat dari nilai peak traffic dibagi dengan Erlang. Berarti dengan itu pada cell ID 58009 nilai utilisasi-nya kurang dari standar dari PT XL AXIATA, Tbk Purwokerto yang sesuai dengan tabel 6 maka harus dilakukan penyimpanan TRX. Dengan itu perlu disimpan 1 TRX untuk meningkatkan nilai utilisasi-nya sehingga menjadi $93,99 \%$. 
Untuk pengaruh TG Synchronization pada site yang lain sama dengan site Gandramangu maka hanya site Gandaramngu yang ditampilkan tapi untuk site yang lain ditampilkan pada lampiran XVI.

\section{Penutup}

\subsection{Kesimpulan}

Berdasarkan hasil analisis, maka dapat diperoleh kesimpulan sebagai berikut:

1. Berdasarkan data yang diambil yaitu $\mathrm{TCH}$ Availability, TCH traffic, SDCCH traffic, $\mathrm{TCH}$ Congestion ratio dan $\mathrm{TCH}$ drop assignment ratio pada bulan Mei 2010 di site Cilongok yang dilakukan TG Synchronization untuk peningkatan kapasitas trafik berhasil. Terjadinya penurunan jumlah TCH Availability diakibatkan pengurangan jumlah TRU pada kabinet, kerusakan pada TRU, dan kerusakan pada Time slot.

2. Peningkatan TCH Drop Assignment Ratio setelah dilakukan TG Synchronization terjadi dikarenakan pengaturan Tilting dan Sector antena pada Slave RBS terhadap Master RBS tidak sama.

3. Pengaruh TG Synchronization pada jumlah TRU dapat menghemat 2 TRU atau lebih.

4. Dengan melakukan TG Synchronization dapat meminimalkan loss resource (tidak dapat melakukan panggilan karena tidak mendapat kanal TCH) yaitu menurunnya nilai TCH Congestion Ratio.
5. Dengan melakukan TG Synchronization dapat melakukan peningkatan kapasitas trafik dengan traffic gain, yang awalnya 2 RBS mempunyai 2 BCCH kemudian ketika dilakukan TG Synchronization maka 2 RBS yang bergabung tersebut hanya memerlukan satu BCCH, terletak di Master RBS. Dengan itu maka akan terjadi peningkatan kapasitas trafiknya, yang awalnya ketika digabungkan 56 time slot akan menjadi 58 time slot karena time slot $\mathrm{BCCH}$ pada slave RBS digunakan untuk kanal TCH. Dan dengan itu juga akan meningkatkan kapasitas dari TCH trafficnya dan SDCCH trafficnya.

6. Dengan melakukan TG Synchronication merupakan salah satu solusi untuk BTS end site high traffic, dapat menambahkan kapasitas trafik tanpa penambahan cell/BTS. Dapat dilihat pada peningkatan $\mathrm{TCH}$ availabilitynya yang meningkat menjadi 2 kali lipat dari awalnya yaitu 28 time slot menjadi 58 time slot.

\subsection{Saran}

1. Untuk pengembangan tugas akhir ini dapat menganalisa data pengaruh tilting antenna pada Master RBS dan Slave RBS.

2. Dapat menganalisa pengaruh kegagalan $\mathrm{TG}$ Synchronization yang disebabkan karena kesalahan pada hardware dan software.

\section{DAFTAR PUSTAKA}


[1] Anonymous. Introduction to GSM. Nokia Telecomunications.

[2] Anonymous. GSM System.

http://mochamadridwan.files.wordpress. com/2007/09/gsm-system.pdf. (diakses tanggal 20 juni 2010) jam 12.30 PM.

[3] Anonymous.TG Sync 2254L1 Kotagede. NetOptim Central. Axiata Company.

[4] Hidayat Eko. How to Impelement Transceiver Group Synchronization. NetOptim Central.

[5]

http://www.scribd.com/doc/33211073/Si stem-Seluler-Gsm(diakses tanggal 22 agustus 2010) jam 3.30 PM.

[6]

http://www.docstoc.com/docs/9558431/ GSM-NETWORK-BASIC (diakses tanggal 20 juni 2010) jam 11.45 PM.

[7] Juanda Eko. Laporan Tugas Akhir Analisa Optimalisasi Jaringan CDMA $20001 X$ untuk Penanggulangan Drop Call BTS. Akademi Teknik Telekomunikasi Purwokerto. November 2008.

[8] Mishra Ajay. R. 2007. Advanced Cellullar Network Planning and Optimisation. John Wiley \& Sons, Ltd.
[9] Setyadillah Febry. Laporan Praktek Kerja Lapangan I pada Divisi Technical Operation Di PT INDOSAT, Tnk. Purwokerto. Akademi Teknik Telekomunikasi Purwokerto. 2009.

[10] Ramamurthi Bhaskar. Edge :3G Evolotion of GSM and GPRS. Ushamartin Academy of Communication Technology. 9-10 Maret 2001.

[11] Rapport Theodore. S. 2002. Wireless Communications Principles and Practice edition II. Prentice Hall.

[12] Stephens James. GSM (Global System for Mobile Communication). 24 mei 2004.

[13] Wello Andi Ulva. T.. Laporan Tugas Akhir Analisis Performansi Pada Jaringan GSM 900/1800 di Area Purwokerto Studi Kasus Di PT EXCELCOMINDO PRATAMA Purwokerto.Akademi Teknik Telekomunikasi Purwokerto. 2009.

[14] Wahyu yuyu dan Rustini S. Kayatmo. Penggunaan Alokasi Kanal TDMA pada Sistem Selular GSM. Jurnal Elektronika dan Telekomunikasi. Januari - Maret 2001. 